\title{
Alteration in the Tegumental Enzymes of Hymenolepis diminuta by Senna spp
}

\section{Suman Kundu ${ }^{1,2}$, Sudeshna Mandal ${ }^{2}$, Chandrani Mondal ${ }^{2}$ and Larisha Mawkhlieng Lyndem ${ }^{2 *}$}

${ }^{1}$ Department of Microbiology, Immunology and Biochemistry University of

Tennessee Health Science Center, Memphis, USA

${ }^{2}$ Parasitology Research laboratory, Department of Zoology, Visva-Bharati, West

Bengal, India

*Corresponding Author: Larisha Mawkhlieng Lyndem, Parasitology Research

laboratory, Department of Zoology, Visva-Bharati, West Bengal, India.
Received: October 04, 2021

Published: October 19, 2021

(C) All rights are reserved by Suman Kundu., et al.

\begin{abstract}
Leaf extracts from three species of Senna viz., S. alata, S. occidentalis, and S. alexandrina induced severe morphological alterations in the zoonotic cestode parasite Hymenolepis diminuta. The present study revealed the anthelmintic effects of these plant extracts on the major tegumental enzymes, acid phosphatase (AcPase), alkaline phosphatase (AlkPase), adenosine tri-phosphatase (ATPase) and 5'nucleotidase (5'- $\mathrm{Nu}$ ) of $\mathrm{H}$. diminuta. The effects have been established by making histochemical localization and biochemical quantification of the tegumental enzyme activities that form the basis of the present communication and would therefore add an in depth understanding to the prior findings. Reduction of enzyme level of more than 20\%, 30\%, 40\% and 50\% of AlkPase, AcPase, ATPase and 5'- Nu respectively were observed in plant extract treated parasites compared to control. This study thus opens new insight of the anthelmintic potential of the three species of Senna and ensures more mechanistic throughput in terms of anthelmintic drug discovery.
\end{abstract}

Keywords: Parasites; Histochemical; Biochemical; Anthelmintic; Tegument

\section{Introduction}

The outer body surface of helminths, the tegument is known to be the major dynamic structure of flatworms especially in cestodes. Several important enzymes are anchored in the tegument either bound to external surface membrane or apparently associated with the internal membrane [1,2]. Enzymes such as acid phosphatase (AcPase), alkaline phosphatase (AlkPase), adenosine triphosphatase (ATPase) and 5'nucleotidase (5'- Nu) were reported to be intimately associated with the tegument and the sub-tegument particularly in the adhesive organs like acetabulum and oral suckers of the platyhelminthes, as well as in the gut and cuticle of nematodes [3-7]. Higher concentrations of AlkPase are located in the intestine and sub-cuticular layers of the worm associated with protein transport and also digestion and absorption of food in the cestode parasites [8]. Thus, any interference or inhibition of these enzymes could lead to depletion of nutrients and ATP production.

In view of the functional significance of these enzymes in digestion and or absorption in cestodes, the present investigation was aimed to study the effect of alcoholic leaf extracts of the three species of Senna plant viz. S. alata (L.) Roxb., S. occidentalis (L.) Linn, and S. alexandrina Mill. on the activity of AcPase, AlkPase, ATPase 
and $5^{\prime}-\mathrm{Nu}$ in the cestode parasite model Hymenolepis diminuta. These three plant species were important to evaluate as they were reported for the first time on the alteration of the surface topography of cestode parasites by Kundu and Lyndem (2012) [9] and Kundu et al. [10-13], besides having other medicinal properties. The anthelmintic effects was established by making histochemical localization and biochemical quantification of the above enzyme activities that form the basis of the present communication.

\section{Materials and Methods}

Drug and chemicals

All the chemicals used were of analytical grade. Ethanol was supplied by Bengal Chemicals, Kolkata, India and Milli-Q water (MilliQ Academic with $0.22 \mathrm{~lm}$ Millipak R-40) was used for the assays. The reference drug Praziquantel is a product of Chandrabhaghat Pharma Pvt Ltd., Mumbai, India. All the salts used for biochemical assay were of analytical grade and obtained from Merck Life Science Pvt. Ltd. India. All enzymes, substrates and other chemicals for pursuing biochemical assays were purchased from Hi-Media Laboratories, Mumbai, India. Cryo-gel for cryo-sectioning was purchased from Thermo Fisher Scientific.

\section{Preparation of ethanol leaf extract of Senna plant}

Freshly collected leaves of S. alata, S. occidentalis and S. alexandrina were collected from our University and processed for ethanolic crude extract following the method described earlier by Kundu and Lyndem 2013 [9].

\section{Collection of parasites and in vitro experimental design}

$H$. diminuta was raised in male Albino rat in our laboratory and the parasites were collected from small intestine. About 5 live worms were incubated in $40 \mathrm{mg} / \mathrm{mL}$ concentration of each leaf extract. Another set of worms was incubated in $0.005 \mathrm{mg} / \mathrm{mL}$ praziquantel prepared in phosphate buffer saline (PBS) (pH 7.4) with $1 \%$ dimethylsulphoxide (DMSO), and 5 more worms were kept as control. The above concentrations were derived as standard doses from our earlier studies $[10,12,13]$. The in vitro treatment was carried out in a humidity cabinet incubator at $37 \pm 1^{\circ} \mathrm{C}$ with proper air circulation till the parasite paralyzed that is when no movement were observed except when kept at slightly warm PBS Immediately after paralysis, worms were washed in PBS and processed for histochemical and biochemical studies. All experimental protocols with rats were approved by the Institutional Animal Ethics Committee (IAEC).

\section{Histochemical studies}

The matured proglottids of the paralysed parasites and control were investigated histochemically as follows.

\section{AcPase enzyme activity}

This enzyme was assayed following lead nitrate method as described by Pearse [14]. The matured proglottid was fixed in cold formol calcium fluid ( $4 \%$ formaldehyde containing $1 \% \mathrm{CaCl}_{2}$ with pH 7.0 at $4{ }^{\circ} \mathrm{C}$ ) overnight. The fixed tissue was washed in water and sections were cut at 10-15 $\mu \mathrm{m}$ thickness under cryomicrotome (Thermo Scientific CryoStar ${ }^{\mathrm{TM}}$ NX70 Cryostat) and the sections were incubated in a $2 \%$ sodium- $\beta$-glycerophosphate substrate at $37^{\circ} \mathrm{C}$ for $2 \mathrm{~h}$. The incubated sections were rinsed in distilled water and dipped in ammoniacal silver nitrate solution (28\% ammonia and $5 \%$ aqueous $\mathrm{AgNO}_{3}$ ) for $30 \mathrm{~min}$. The sections were further rinsed in 5\% sodium thiosulphate for $5 \mathrm{~min}$, and dehydrated with different grades of alcohol and mounted in Canada balsam. Brownish precipitates indicated activity sites of AcPase.

\section{AlkPase enzyme activity}

The enzyme activity was determined by coupling Azo-dye method of Pearse [14]. The matured proglottid was fixed in $10 \%$ neutral buffered formalin (NBF) at $4^{\circ} \mathrm{C}$ for 10-16 h. Later, tissue sections were prepared at 10-15 $\mu \mathrm{m}$ thickness in cryomicrotome and stained with Fast violet B. (2-benzoxylamine-4-methoxytoluidine) for 15-60 min. The tissue sections were subsequently stained in Mayer's haemalum for 1-2 min, and then washed in water for 30-60 min and mounted in glycerin jelly. Brown colored with dark nuclei indicated presence of the enzyme.

\section{ATPase enzyme activity}

The activity of the enzyme was achieved through calcium method Pearse [14]. The matured proglottids were incubated in $10 \%$ $\mathrm{NBF}$ at $4^{\circ} \mathrm{C}$ for $10-16 \mathrm{~h}$. Later tissue sections were cut at of 10-15 $\mu \mathrm{m}$ thickness and incubated in a freshly prepared incubation medium (containing $0.1 \mathrm{M}$ glycine and $0.4 \mathrm{M} \mathrm{KCl}$ in saturated sodium acetate, $0.36 \mathrm{M} \mathrm{CaCl}_{2}, 1.0 \mathrm{M} \mathrm{KOH}, 0.04 \mathrm{M} \mathrm{Na}$-ATP, distilled water and saturated sodium phosphate) for $3 \mathrm{~h}$. The sections were then washed in $1 \% \mathrm{CaCl}_{2}$ prepared in $75 \%$ ethanol, and transferred to $2 \%$ cobalt chloride for $3 \mathrm{~min}$ and the tissue was then developed

Citation: Suman Kundu, Sudeshna Mandal, Chandrani Mondal and Larisha Mawkhlieng Lyndem. "Alteration in the Tegumental Enzymes of Hymenolepis diminuta by Senna spp". Acta Scientific Microbiology 4.11 (2021): 39-45. 
in $1 \%$ yellow ammonium sulphide, and mounted in glycerin jelly. Blackish brown precipitate indicated the presence of ATPase.

\section{5'-NU enzyme activity}

The enzyme activity was determined by the lead method of Wachstein and Meisel [15] using adenosine monophosphate (AMP) as the substrate. The parasite proglottid was fixed in cold formol calcium (pH-7.0) at $4^{\circ} \mathrm{C}$ for overnight. It was later washed in water and frozen sectioned at10-15 $\mu \mathrm{m}$ thickness and incubated in the reaction medium [1.25\% AMP, $0.2 \mathrm{M}$ Tris-buffer, $0.2 \% \mathrm{~Pb}\left(\mathrm{NO}_{3}\right)_{2}$ and $\left.0.1 \mathrm{M} \mathrm{MgSO}_{4}\right]$ at $37{ }^{\circ} \mathrm{C}$ for $30 \mathrm{~min}$. The reaction was stopped with the addition of $2 \mathrm{ml}$ of $40 \%$ formaldehyde for $30 \mathrm{~min}$. Sections were then treated with dilute yellow ammonium sulphide for 2 min and again rinsed with double distilled water and mounted in glycerine jelly. Yellow deposits of lead sulphide indicate sites of 5'-Nu enzyme activity.

\section{Biochemical studies}

Activity of AcPase and AlkPase was measured by estimating the p-nitrophenol formation following the method of Plummer [16] with some modifications. A $10 \%$ tissue homogenate was prepared in $125 \mathrm{mM}$ sodium-acetate buffer ( $\mathrm{pH} 4.5$ ) and sodium-glycine buffer ( $\mathrm{pH} 10.5)$ for AcPase and AlkPase respectively and centrifuged at 5,000 rpm for $20 \mathrm{~min}$ at $4^{\circ} \mathrm{C}$. The supernatant was collected for the enzyme study. Using p-nitrophenyl phosphate as substrate the enzyme activity was measured through absorbance at $412 \mathrm{~nm}$ in a UV-visible spectrophotometer (Beckman).

The ATPase activity was measured following the method described by Pal and Tandon [17] by using Na-ATP as a substrate. A $10 \%$ tissue homogenate was prepared in $0.1 \mathrm{M}$ Tris- $\mathrm{HCl}$ buffer $(\mathrm{pH}$ 7.5). In a final volume of $1 \mathrm{~mL}$ reaction mixture [containing $0.1 \mathrm{M}$ Tris- $\mathrm{HCl}$ buffer, $3 \mathrm{mM}$ ATP- $\mathrm{Na}_{2}, 30 \mathrm{mM} \mathrm{MgCl}, 100 \mathrm{mMNaCl}$ and 20 $\mathrm{mMKCl}$ ], $0.2 \mathrm{~mL}$ of tissue homogenate was added and the mixture was incubated for 1 hour. After which $1 \mathrm{~mL}$ of $10 \%$ trichloro acetic acid (TCA) was added. The mixture was centrifuged for $10 \mathrm{~min}$ at $4,000 \mathrm{rpm}$ at $37^{\circ} \mathrm{C}$. Inorganic phosphate was determined from the supernatant by the method of Fiske and Subbarow [18]. Similarly, blank was prepared following the same method except the TCA was added before the addition of tissue homogenate.

5'Nu activity was assayed by estimating the free phosphate, following the modified method of Buniatian [19]. A 10\% (w/v) tissue homogenate was centrifuged at $3000 \mathrm{rpm}$ at $4^{\circ} \mathrm{C}$ and the su- pernatant was used as the enzyme source. $1 \mathrm{~mL}$ reaction mixture containing Tris-HCl buffer (40 mM, pH 7.5), $\mathrm{MgSO}_{4}(10 \mathrm{mM})$, AMP $(5 \mathrm{mM})$, and tissue extract $(0.1 \mathrm{~mL})$, was incubated at $37^{\circ} \mathrm{C}$ for $1 \mathrm{~h}$ and the liberated inorganic phosphate was estimated determined by the method of Fiske and Subbarow [18]. One unit of enzyme activity was defined as the amount of product formed per hour per gram tissue. Specific activity is expressed as units/mg protein.

Protein was estimated following the method of Lowry et al. [20], using bovine serum albumin as the standard. The specific activity of the enzyme was expressed as the unit of enzyme activity per mg protein (unit activity/mg protein). A $10 \mu \mathrm{L}$ protein sample (tissue supernatant) was pipetted out to different test tubes and distilled water was added up to a volume of $1 \mathrm{~mL}$. About $2.5 \mathrm{~mL}$ of Lowry's reagent was added to each tube and gently mixed. This solution was incubated at room temperature for 10 min. Further 250 $\mu \mathrm{L}$ of diluted Folin Ciocalteau reagent solution was added to each tube and incubated for $30 \mathrm{~min}$. The optical density was recorded at $660 \mathrm{~nm}$ and the absorbance against protein concentration was plotted to get a standard calibration curve. The absorbance of the unknown sample was noted and its concentration was determined using the standard curve plotted.

\section{Results and Discussion}

The present study showed deep brown stain on the tegument, sub-tegument the somatic musculature and inner parenchyma layer of the control parasite suggested the presence of enzyme AcPase (Figure 1a). Similar observation was observed in other cestode parasites, indicated that the enzyme possessed significant role in absorption as the tegument is the only interface where the parasite obtained food from its host. However, in all the plant treated parasites deep brown color was absent in the tegument (Figure $1 \mathrm{~b}, \mathrm{c}$ and d respectively), and praziquantel showed blackish brown (Figure 1e). AcPase total activity was observed as $888.51 \pm 4.98$ unit/g wet wt. tissue/h. in control. The enzyme activity reduced significantly by $45 \%$ in S. occidentalis followed by S. alata (37\%) S. alexandrina (31\%) and praziquantel (26\%) from that of the control (Table 1). Depletion of the stain suggested a significant decrease in enzyme activity and AcPase being associated with lysosomes and is regarded as membrane transport mechanism [21]. Thus inhibition of AcPase activity by the plant extracts might alter absorption and transport of food materials across the tegument. This depletion could be due to leakage of the enzyme into the medium as a result of disruption of the tegument $[22,23]$.

Citation: Suman Kundu, Sudeshna Mandal, Chandrani Mondal and Larisha Mawkhlieng Lyndem. "Alteration in the Tegumental Enzymes of Hymenolepis diminuta by Senna spp". Acta Scientific Microbiology 4.11 (2021): 39-45. 


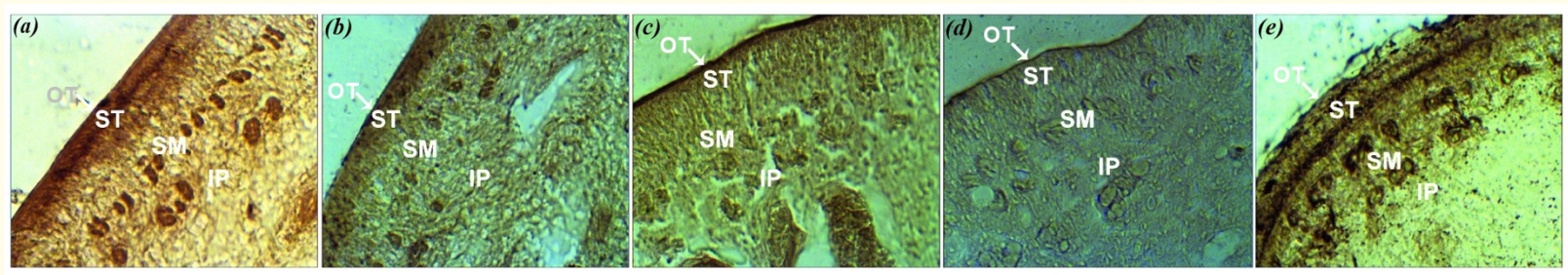

Figure 1: Acid phosphatase activity in H. diminuta: (a) Control -showed brown deposits in the outer tegument (OT), sub tegument (ST), somatic musculature (SM) and inner parenchyma (IP); (b) S. occidentalis and (c) S. alexandrina - scattered brown deposits showed in ST and SM; (d) S. alata- no brown colour deposits in the whole tegument and (e) Praziquantel- showed blackish brown in OT, ST and SM.

\begin{tabular}{|c|c|c|c|c|c|c|c|c|}
\hline \multirow{2}{*}{ Treatment } & \multicolumn{4}{|c|}{ Enzymes activity (Total/ specific activity) } & \multicolumn{4}{|c|}{$\%$ Change after treatment } \\
\hline & AcPase & AlkPase & ATPase & $5^{\prime}-\mathrm{Nu}$ & AcPase & AlkPase & ATPase & $5^{\prime}-\mathrm{Nu}$ \\
\hline Control & $\begin{array}{c}888.51 \pm 4.98 / \\
0.85 \pm .003\end{array}$ & $\begin{array}{c}2173.1 \pm 14 / \\
2.09 \pm .015\end{array}$ & $\begin{array}{c}4445.54 \pm 40.41 / \\
4.29 \pm 0.04\end{array}$ & $\begin{array}{c}515.83 \pm 5.51 \\
0.5 \pm 0.006\end{array}$ & & & & \\
\hline Praziquantel & $\begin{array}{c}661.35 \pm 5.75 / \\
0.75 \pm 0.007\end{array}$ & $\begin{array}{c}1537.63 \pm 18.68 / \\
1.73 \pm 0.020\end{array}$ & $\begin{array}{c}1507.32 \pm 23.27 \\
1.93 \pm 0.03\end{array}$ & $\begin{array}{c}265.76 \pm 4.12 / \\
0.34 \pm 0.006\end{array}$ & 26 & 30 & 67 & 49 \\
\hline S. alata & $\begin{array}{c}566.46 \pm 12.54 / \\
0.72 \pm 0.015\end{array}$ & $\begin{array}{c}1628.93 \pm 13.99 / \\
1.77 \pm 0.015\end{array}$ & $\begin{array}{c}1906.56 \pm 15.56 / \\
2.51 \pm 0.02\end{array}$ & $\begin{array}{c}222.89 \pm 6.37 / \\
0.29 \pm 0.007\end{array}$ & 26 & 30 & 67 & 49 \\
\hline S. alexandrina & $\begin{array}{c}566.46 \pm 12.54 / \\
0.72 \pm 0.015\end{array}$ & $\begin{array}{c}1628.93 \pm 13.99 / \\
1.77 \pm 0.015\end{array}$ & $\begin{array}{c}1906.56 \pm 15.56 / \\
2.51 \pm 0.02\end{array}$ & $\begin{array}{c}222.89 \pm 6.37 / \\
0.29 \pm 0.007\end{array}$ & 31 & 24 & 44 & 58 \\
\hline S. occidentalis & $\begin{array}{l}491.7 \pm 9.96 / \\
0.59 \pm 0.015\end{array}$ & $\begin{array}{c}922.29 \pm 34.02 / \\
1.04 \pm 0.042\end{array}$ & $\begin{array}{c}2384.42 \pm 15.13 \\
2.84 \pm 0.02\end{array}$ & $\begin{array}{l}246.9 \pm 4.31 / \\
0.29 \pm 0.007\end{array}$ & 45 & 58 & 47 & 53 \\
\hline
\end{tabular}

Table 1: Effect of ethanolic extract of three species of Senna plant on the tegumental enzymes of H. diminuta.

For AlkPase activity, the control parasite showed distinct brown color in the tegument (Figure 2a), while in all treated worms the color is either depleted or blackish brown precipitates were observed (Figure 2b, c, d and e). Though histochemically, AcPase showed more stain intensity than AlkPase but biochemically AlkPase was observed to be higher than AcPase (Table 1). The presence of these two enzymes in the parasite's tegument indicated that they both function in the absorptive digestion capacity analo- gous to the mucosal lining of the vertebrate intestine [23]. AlkPase activity was observed as $2173.10 \pm 14.00$ unit/g wet wt. tissue/h. in control but reduced significantly by $58 \%$ reduction in S. occidentalis followed by praziquantel (30\%), S. alata (26\%) and S. alexandrina (24\%) from that of the control (Table 1). Similar alteration in enzyme activity was also reported by other workers [24,25]. Inhibition of AlkPase activity might affect membrane transport, complete inhibition of glucose uptake in the body of the parasite. 


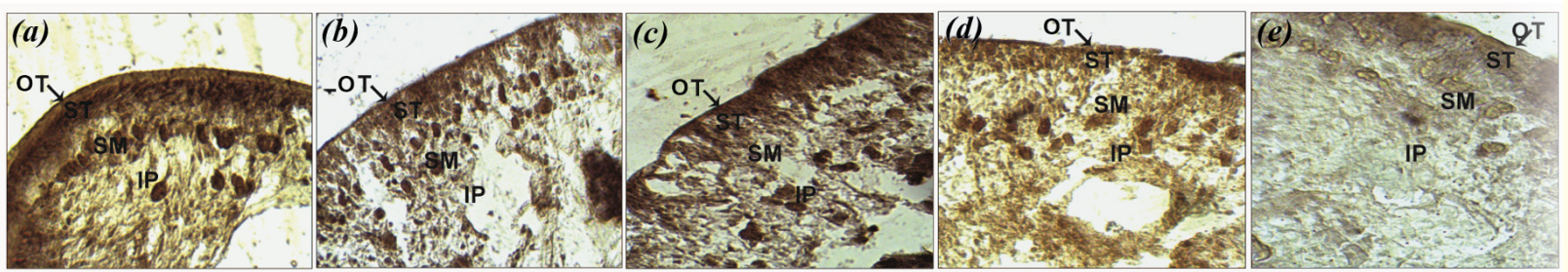

Figure 2: Alkaline phosphatase activity in H. diminuta: (a) Control (b) S. occidentalis and (c) S. alexandrina showed dark brown stain in outer tegument (OT), sub tegument (ST), somatic musculature (SM); (d) S. alata-showed inconsistent brown colour and (e) Praziquantel- showed no noticeable dark brown stain.

Purplish black color was observed in the outer tegument, subtegument, somatic musculature and inner parenchyma of control parasite (Figure 3a) indicated high activity of ATPase, whereas no noticeable black color was observed in all treated parasites suggested that the enzyme activity was reduced (Figure 3b, 3c, 3d, 3e). ATPase is involved in the synthesis and hydrolysis of ATP and is known to be related to energy metabolism, active transport and lipid synthesis [26]. ATPase was found to be $4445.54 \pm 40.41 \mathrm{unit} / \mathrm{g}$ wet wt. tissue/h. in control and decreased significantly by $67 \%$ in praziquantel followed by $57 \%, 47 \%$ and $44 \%$ in S. alata, S. occidentalis and S. alexandrina respectively from that of the control (Table 1). Similar observation was reported in E. multilocularis after treated with mebendazole and levamisole. Inhibitions of this enzyme activity were also seen in other helminths treated with drugs or plant extracts [27]. The observed reduction in ATPase might be associated with inhibition or reduced uptake of glucose in H. diminuta leading to gradual loss of motor activity due to deprivation of energy source and thus, culminated to paralysis.
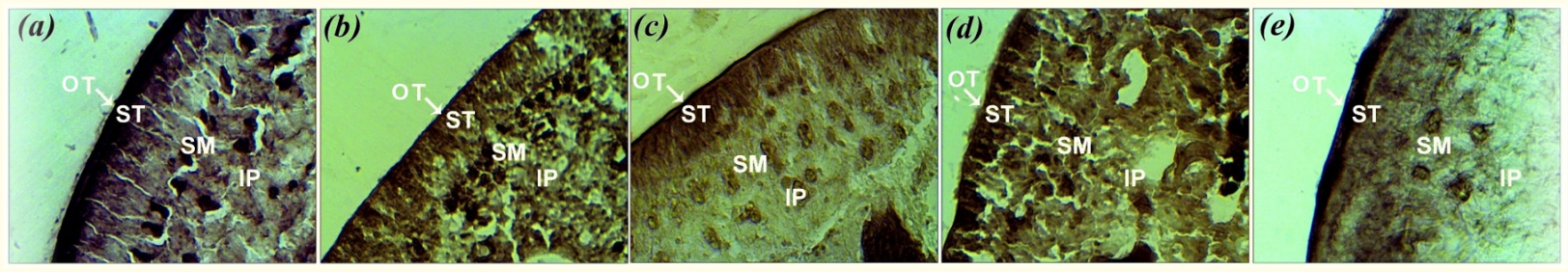

Figure 3: Adenosine tri-phosphatase activity in H. diminuta:(a) Control- showed deep purple stain in the outer tegument (OT), sub tegument (ST), somatic musculature (SM) and inner parenchyma IP; (b) S. occidentalis (c) S. alexandrina (d) S. alata and (e) Praziquantel- showed absence of purple stain.

Yellow deposits were observed in sub tegument and sub muscular layer of the body surface of control parasite (Figure 4a) as well as in S. occidentalis and S. alexandrina treated parasites (Figure $4 \mathrm{~b}$ and 4c), indicated presence of 5'-Nu. However, the low expression of yellow stain in S. alata and praziquantel (Figure $4 \mathrm{~b}$ and $4 \mathrm{~d}$ ), indicated less abundance of $5^{\prime}-\mathrm{Nu}$. More than $50 \%$ reduction in $5^{\prime} \mathrm{Nu}$ activity was observed in $H$. diminuta after treatment (Table 1 ). Sim- ilar reduction pattern was also reported in Raillietina echinobothrida [18]. In helminths, 5'-Nu may be involved with other enzymes in the uptake of nucleosides or their hydrolysis to pyrimidine and purine bases $[21,28]$. As this enzyme is associated with the active transport of plasma membrane there might be a decrease in the uptake of food materials due to the immense structural alteration of the tegument. 


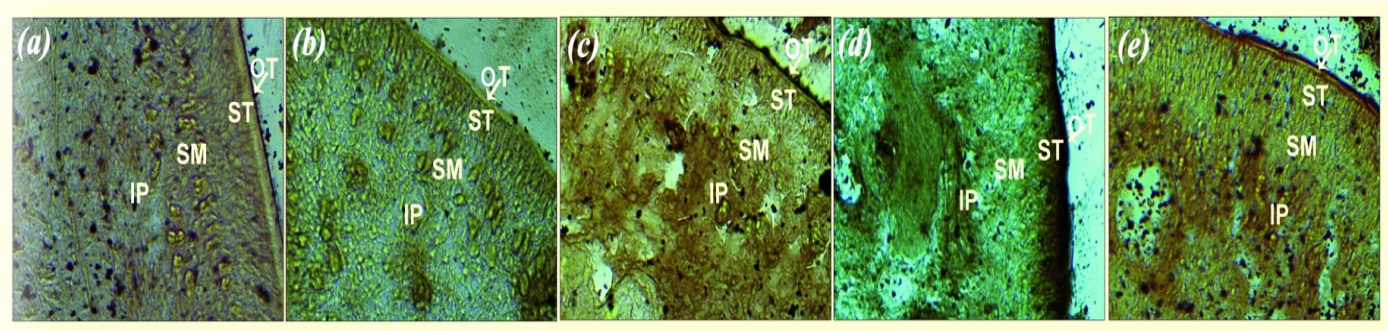

Figure 4: 5' Nucleotidase activity in H. diminuta: (a) Control and (b) S. occidentalis - showed yellow deposits in sub tegument (ST), somatic musculature (SM) and inner parenchyma IP; showed (c) S. alexandrina showed yellow deposits only in SM; (d) S. alata showed no yellow deposits and (e) Praziquantel showed faint yellow deposits only in IP.

The present study thus open new insight of the anthelmintic potential of the three Senna plant species and thus ensue a more mechanistic throughput in terms of anthelmintic drug discovery.

\section{Conclusions}

The present study thus indicated that the ethanol extracts of the three Senna plant species altered and reduced the activity of the major tegumental enzymes, AcPase, AlkPase, ATPase and 5'-Nu of the cestode parasite $H$. diminuta. This reduction could cause decrease in the uptake of food material, synthesis and hydrolysis of ATP which might lead to energy dearth on the parasite and early paralysis.

\section{Acknowledgements}

The authors gratefully acknowledge the University Grants Commission (UGC), BSR-UGC Research Fellowship in Science for Meritorious Students to the first author. We also wish to thank the Department of Zoology, Visva-Bharati for providing infrastructural support.

\section{Conflict of Interests}

The authors declare that they have no conflict of interest.

\section{Bibliography}

1. Cumino AC., et al. "Echinococcus granulosus tegumental enzymes as in vitro markers of pharmacological damage: a biochemical and molecular approach". Parasitology international 61.4 (2012): 579-585.
2. McManus DP. "Reflections on the biochemistry of Echinococcus: past, present and future". Parasitology 136.12 (2009): 1643-1652.

3. Buchmann K. "Histochemical characteristics of Gyrodactylus derjavini parasitizing the fins of rainbow trout (Oncorhynchus mykiss)". Folia parasitologica 45.4 (1998): 312-318.

4. Fried B., et al. "Histochemical localization of alkaline phosphatase activity in Leucochloridiomorpha constantiae (Trematoda) cultivated on the chick chorioallantois". The Journal of Parasitology 71.4 (1985): 510-512.

5. Huh S. "Activities of acid phosphatase and non-specific esterase are present in the tribocytic organ and the caecum of Fibricola seoulensis". The Korean Journal of Parasitology 31.2 (1993): 165-167.

6. Marr J., et al. Molecular medical parasitology. Elsevier (2002).

7. Roy B and Swargiary A. "Anthelmintic efficacy of ethanolic shoot extract of Alpinia nigra on tegumental enzymes of Fasciolopsis buski, a giant intestinal parasite". Journal of Parasitic Diseases 33.1-2 (2009): 48-53.

8. Cesari IM., et al. "Properties of a series of tegumental membrane-bound phosphohydrolase activities of Schistosoma mansoni". Biochemical Journal 198.3 (1981): 467-473.

9. $\quad$ Kundu S and Lyndem LM. "In vitro screening for cestocidal activity of three species of Cassia plants against the tapeworm 
Raillietina tetragona". Journal of Helminthology 87.2 (2013): 154-159.

10. Kundu S., et al. "Cassia alata L: potential role as anthelmintic agent against Hymenolepis diminuta". Parasitology Research 111.3 (2012): 1187-1192.

11. Kundu S., et al. "Broad spectrum anthelmintic potential of Cassia plants". Asian Pacific Journal of Tropical Biomedicine 4 (2014): S436-S441.

12. Kundu S., et al. "In vitro anthelmintic effects of Senna occidentalis (L.) link (Leguminosae) on rat tapeworm Hymenolepis diminuta". International Journal of Pharmacy and Pharmaceutical Sciences Sci 7.6 (2015): 268-271.

13. Kundu S., et al. "Senna alexandrina Mill. induced ultrastructural changes on Hymenolepis diminuta". Journal of Parasitic Diseases 41.1 (2017): 147-154.

14. Pearse AG. "Histochemistry, theoretical and applied". (1953). Little brown and Company, Boston.

15. Wachstein M and Meisel E. "Histochemistry of hepatic phosphatases at a physiologic $\mathrm{pH}$ : With special reference to the demonstration of bile canaliculi". American Journal of Clinical Pathology 27.1 (1957): 13-23.

16. Plummer DT. Introduction to practical biochemistry. Tata McGraw-Hill Education (2006).

17. Pal $\mathrm{P}$ and Tandon V". Anthelmintic efficacy of Flemingia vestita (Leguminoceae): Genistein-induced alterations in the activity of tegumental enzymes in the cestode, Raillietina echinobothrida". Parasitology International 47.3 (1998): 233-243.

18. Fiske Cyrus H and Yellapragada Subbarow. "The colorimetric determination of phosphorus". Journal of Biological Chemistry 66.2 (1925): 375-400.

19. Buniatian HC. "Deamination of nucleotides and the role of their deamino forms in ammonia formation from amino acids". Metabolic Reactions in the Nervous System. Springer, Boston, MA (1970): 399-413.

20. Lowry OH., et al. "Protein measurement with the Folin phenol reagent". The Journal of Biological Chemistry 193.1 (1951): 265-275.
21. Pappas PW. "Activation and inhibition of the brush-border membrane-bound alkaline phosphatase activity of Hymenolepis diminuta (Cestoda) by divalent cations". Parasitology 102.1 (1991): 141-145.

22. Hart RJ., et al. "A biochemical and ultrastructural study of the mode of action of bunamidine against Hymenolepis nana". International Journal for Parasitology 7.2 (1977): 129-134.

23. Mehlhorn HBPHJ., et al. "In vivo and in vitro experiments on the effects of praziquantel on Schistosoma mansoni. A light and electron microscopic study". Arzneimittel-forschung 31.3a (1981): 544-554.

24. Lalchhandama K., et al. "Effects of Millettia pachycarpa on the trace metals and tegumental enzymes of Raillietina echinobothrida". Pharmacognosy Magazine 4.16 (2008): 254.

25. Das B., et al. "Potentilla fulgens (Family Rosaceae), a medicinal plant of north-east India: a natural anthelmintic?" Journal of Parasitic Diseases 34 (2010): 83-88.

26. Smyth JD and McManus DP. "The physiology and biochemistry of cestodes". Cambridge university press (1989).

27. Fonseca-Salamanca F., et al. "Nematocidal activity of nitazoxanide in laboratory models". Parasitology Research 91.4 (2003): 321-324.

28. Delabre-Defayolle I., et al. "Echinococcus multilocularis metacestodes: biochemical and ultrastructural investigations on the effect of isatin (2-3 indoline dione) in vivo". Journal of Antimicrobial Chemotherapy 23.2 (1989): 237-245.

\section{Volume 4 Issue 11 November 2021 \\ (C) All rights are reserved by Suman Kundu., et al.}

